Article

\title{
Fermented Apple Pomace as a Feed Additive to Enhance Growth Performance of Growing Pigs and Its Effects on Emissions
}

\section{Chandran M. Ajila ${ }^{1}$, Saurabh J. Sarma ${ }^{1}$, Satinder K. Brar ${ }^{1, *}$, Stephane Godbout ${ }^{2}$, Michel Cote $^{2}$, Frederic Guay ${ }^{3}$, Mausam Verma ${ }^{2,4}$ and Jose R. Valéro ${ }^{1}$}

1 INRS-ETE, Université du Québec, 490, Rue de la Couronne, QC G1K 9A9, Canada; E-Mails: ajilaa@yahoo.com (C.M.A.); Saurabh_Jyoti.Sarma@ete.inrs.ca (S.J.S.); josevalero@videotron.ca (J.R.V.)

2 Institut de recherche et de développement en agroenvironnement inc (IRDA), 2700 rue Einstein, QC G1P 3W8, Canada; E-Mails: stephane.godbout@irda.qc.ca (S.G.); michel.cote@irda.qc.ca (M.C.); mausamverma@yahoo.com (M.V.)

3 Department of Animal Science and Center de Recherche en Biologie de la Reproduction, Laval University, Sainte-Foy, QC G1K 7P4, Canada; E-Mail: frederic.Guay@fsaa.ulaval.ca

$4 \mathrm{CO}_{2}$ Solutions Inc., 2300, rue Jean-Perrin, QC G2C 1T9, Canada

* Author to whom correspondence should be addressed; E-Mail: Satinder.Brar@ete.inrs.ca or satinderbrar2003@yahoo.ca; Tel.: +1-418-654-3116; Fax: +1-418-654-2600.

Academic Editor: Stephen R. Smith

Received: 29 January 2015 / Accepted: 29 May 2015 / Published: 8 June 2015

\begin{abstract}
Apple pomace is a by-product from the apple processing industry and can be used for the production of many value-added compounds such as enzymes, proteins, and nutraceuticals, among others. An investigation was carried out to study the improvement in the protein content in apple pomace by solid-state fermentation using the fungus Phanerochaete chrysosporium by tray fermentation method. The effect of this protein in terms of how it enriched apple pomace as animal feed for pigs has also been studied. There was a $36 \%$ increase in protein content in the experimental diet with $5 \% \mathrm{w} / \mathrm{w}$ fermented apple pomace. The efficiency of conversion of ingested food was increased from $43.5 \pm 2.5$ to $83.1 \pm 4.4$ in the control group and the efficiency of conversion of feed increased from $55.4 \pm 4.5$ to $92.1 \pm 3.6$ in the experimental group during the animal feed experiment. Similarly, the effect of a protein enriched diet on odor emission and greenhouse gas emission has also been studied. The results demonstrated that the protein enrichment of apple pomace
\end{abstract}


by solid state cultivation of the fungus $P$. chrysosporium makes it possible to use it as a dietary supplement for pigs.

Keywords: apple pomace; P. chrysosporium; fermentation; protein enrichment; animal feed; greenhouse gas emission

\section{Introduction}

The production and processing of fruits into different products, such as fruit juices, flavors and concentrates, result in the production of a large quantity of fruit processing by-products, such as pomace. Generally, the apple processing industry generates $25 \%-30 \%$ apple pomace and 5\%-10\% sludge. Apple pomace residues are normally rich in carbohydrates, and other functionally important bioactive compounds, such as polyphenols and other natural antioxidants. Fruit and vegetable residues have been successfully used for protein enrichment and for bioconversion into value-added products, such as enzymes and other metabolites [1]. Apple pomace is presently used to feed animal or simply added to soil as a fertilizer. Several factors adversely affect the value of apple pomace as an animal feed. Firstly, the residue has low digestibility due to high lignin/cellulose ratio. Secondly, the protein, vitamin and mineral contents of apple pomace are low, which contribute to the low nutritional level and consequently lower commercial value of the residue. From an animal nutrition point of view, apple pomace is not a suitable feed as it is deficient in digestible protein [2]. Recently, Saccharomyces cerevisiae was used to increase protein levels of pineapple waste by Solid State fermentation (SSF) with and without nitrogen supplementation [3].

The apple pomace can be used for the production of the high protein enriched residue that can serve as animal feed [4]. It was reported that the growth of yeast on apple pomace increases protein and vitamin content. However, the lower level of fermentable sugars limits protein enrichment of the pomace by yeasts; a major portion of the pomace comprises lignocelluloses. The co-culture of Candida utilis and Aspergillus niger increased the protein content of dried and pectin-extracted apple pomace to $20 \%$ and $17 \%$, respectively, under SSF conditions [5]. The combination of fermented apple pomace with standard feed in the ratio of 1:1 was found to be acceptable during animal experiment with rat model [6]. The apple pomace based feed had also been evaluated successfully in poultry, when mixed with standard poultry feed in 1:1. There was an increase in body weight of broiler from 6th week to 8th week in all the groups where the mean body weight increased from 270 to $537 \mathrm{~g}$ [7].

The agricultural sector is one of the main sources of greenhouse gas (GHG) emissions worldwide and the magnitude of its contribution changes from country to country. It was reported that globally, livestock are responsible for $18 \%$ of greenhouse gas emissions [8]. Reducing or mitigating greenhouse gases (GHG) from livestock systems can play a vital role in providing solutions to climate change obligations. The major greenhouse gases generated by cattle production include methane $\left(\mathrm{CH}_{4}\right)$ and nitrous oxide $\left(\mathrm{N}_{2} \mathrm{O}\right)$, which has global warming potential of 21 and 310 times that of $\mathrm{CO}_{2}$ respectively, making them very potent GHGs. Many attempts have been made to mitigate greenhouse gas emissions without altering animal performance by dietary manipulation [8]. It was reported that emissions per kilogram of livestock product seem to be lower for monogastric than for ruminant animals, partly 
because pigs and poultry have better feed-conversion efficiency than ruminants and also they do not emit enteric methane while digesting their feed [9]. Emissions of GHGs from pork are lower than for beef, and produce very small amount of methane in their feed digestion and production is dominated by nitrous oxide [10].

The alteration in protein concentration in animal feed has been proposed as a means of mitigating GHG, especially methane. It was reported that increasing dietary crude protein concentration from 120 to $150 \mathrm{~g} / \mathrm{kg} \mathrm{DM}$ (digestible matter) in dairy cows significantly reduced methane emission as a proportion of dry matter intake and milk yield and further increasing dietary crude protein concentration to $180 \mathrm{~g} / \mathrm{kg}$ DM had no effect [11]. Increasing dietary concentrate level reduced methane emission as a proportion of feed intake and milk yield.

The objectives of the present investigation were to study the protein enrichment of apple pomace by the process of solid-state fermentation using P. chrysosporium and its addition as a protein supplement to the diet of pigs and study the growth performance of animals. The present investigation also studied the effect of these protein enriched diets on the reduction of GHG emissions.

\section{Results and Discussion}

\subsection{Proximate Composition in the Control and Experimental Diet with Fermented Apple Pomace}

The proximate composition of the control and experimental diet which was formulated with protein enriched apple pomace by Phanerochaete chrysosporium under solid state fermentation (SSF) is given in Table 1 . There was $36 \%$ increase in protein content $(15.85 \%$ to $24.81 \%$ ) by the addition of $5 \% \mathrm{w} / \mathrm{W}$ protein enriched apple pomace by solid state fermentation. The analysis of most of other nutrients and minerals showed no significant difference $(p<0.05)$ between the control diet and experimental diet with protein enriched apple pomace.

Table 1. Proximate composition of control and experimental diet.

\begin{tabular}{ccc}
\hline Component & \multicolumn{2}{c}{ On Dry Weight Basis } \\
\cline { 2 - 3 } & Control Diet & Experimental Diet \\
\hline Dry matter $(\%)$ & $89.50 \pm 0.10$ & $89.55 \pm 0.15$ \\
Crude Protein $(\%)$ & $15.85 \pm 0.05$ & $24.81 \pm 0.2$ \\
Lipid (\%) & $5.62 \pm 0.08$ & $4.57 \pm 0.01$ \\
Ash (\%) & $3.55 \pm 0.29$ & $4.06 \pm 0.03$ \\
NDF $(\%)$ & $9.82 \pm 0.14$ & $10.55 \pm 0.45$ \\
ADF $(\%)$ & $3.95 \pm 0.05$ & $3.88 \pm 0.24$ \\
Phosphorus $(\mathrm{mg} / \mathrm{kg})$ & $6032 \pm 130$ & $5241 \pm 95$ \\
Potassium $(\mathrm{mg} / \mathrm{kg})$ & $6757 \pm 27$ & $7053 \pm 13$ \\
Calcium $(\mathrm{mg} / \mathrm{kg})$ & $5946 \pm 407$ & $4712 \pm 73$ \\
Sodium $(\mathrm{mg} / \mathrm{kg})$ & $1551 \pm 40$ & $1847 \pm 197$ \\
Boron $(\mathrm{mg} / \mathrm{kg})$ & $09.37 \pm 0.15$ & $12.95 \pm 0.95$ \\
Aluminum $(\mathrm{mg} / \mathrm{kg})$ & $146 \pm 3.5$ & $146 \pm 2$ \\
Copper $(\mathrm{mg} / \mathrm{kg})$ & $27.35 \pm 1.75$ & $30.00 \pm 1.2$ \\
Iron $(\mathrm{mg} / \mathrm{kg})$ & $258 \pm 3$ & $231 \pm 5$ \\
Magnesium $(\mathrm{mg} / \mathrm{kg})$ & $1484 \pm 19$ & $1462 \pm 1$ \\
Manganese $(\mathrm{mg} / \mathrm{kg})$ & $62.45 \pm 0.25$ & $62.95 \pm 0.05$ \\
Zinc $(\mathrm{mg} / \mathrm{kg})$ & $321 \pm 17$ & $195 \pm 12$ \\
\hline
\end{tabular}

All data are the mean $\pm \mathrm{SD}$ of three replicates. 
Earlier, it was reported that co-culture of Candida utilis and Aspergillus niger increased the protein content of dried and pectin-extracted apple pomace to $20 \%$ and $17 \%$, respectively, under SSF conditions [5]. In solid state fermentation, the microorganisms hydrolyze the cellulose or hemicellulose component of the pomace by secreting extracellular enzymes (cellulases and xylanases) and then use the released sugar as carbon source for growth. This results in better utilization of the substrate than the microorganism could achieve independently. The higher yield of protein would have possibly resulted from the enzymatic hydrolysis of the lignocellulosic component of the pomace which was later used by the microorganisms. Phanerochaete chrysosporium has been already reported to produce ligninolytic and carbohydrate metabolizing enzymes during solid state fermentation of apple pomace [12].

Carbohydrate content of apple pomace could be as high as 85\% [12] and Zheng and Shetty (1998) used it to produce a food rich in proteins by employing the fungus, Rhizopus oligosporus [13]. Bisaria et al. (1997) used the fungus Pleurotus sajor-caju in the bioconversion of rice straw and wheat straw and they found that supplementation of the solid residue with urea and ammonium nitrate increased the protein level from $2.87 \%$ to $6.3 \%(\mathrm{w} / \mathrm{w})$ with rice straw and from $3.1 \%$ to $7.5 \%(\mathrm{w} / \mathrm{w})$ with wheat straw [14]. Solid state fermentation of apple pomace blended with $10 \%$ molasses and $1.8 \%$ ammonium sulfate as a nitrogen source resulted in increased crude protein content [4]. Compared to these reports, as already mentioned, the protein content can be increase from $15.85 \%$ to $24.81 \%$ with the addition of $5 \% \mathrm{w} / \mathrm{w}$ protein enriched apple pomace from the present study.

\subsection{Effect of Protein Enriched Diet on Growth Performance}

With the objective of testing the apple pomace treated biologically with $P$. chrysosporium as a food supplement in animal feed, two diets were provided to the animals. The diets used over a period of four weeks were conventional feed and conventional feed amended with the addition of $5 \%(\mathrm{w} / \mathrm{w})$ treated apple pomace (Table 2). Table 3 presents the effects of protein enriched diet on average daily gain on growing pigs and also on growth performance of the growing pigs during the experiment. The average daily gain for control diet group ranged from $0.72 \pm 0.13 \mathrm{~kg}$ /day to $2.4 \pm 0.11 \mathrm{~kg} /$ day and for the experimental diet from $0.64 \pm 0.05 \mathrm{~kg}$ /day to $2.60 \pm 0.08 \mathrm{~kg}$ /day during the experimental period. The results of comparisons of feed conversion ratio are presented in Figure 1. The feed conversion is calculated by dividing the amount of feed fed by amount of pig weight gain. The feed conversion ratio was found to be lower in the experimental diet group than the control group.

Table 2. Composition of the basic diet.

\begin{tabular}{cc}
\hline Component & On Dry Weight Basis (\% w/w) \\
\hline Maize & 82.09 \\
Soya & 15.79 \\
Limestone & 0.95 \\
Phosphate & 0.42 \\
Lysine-HCl & 0.21 \\
Vitamin Premix PorcCroiss & 0.21 \\
Phytase 5000 (Phyzyme) & 0.01 \\
$\mathrm{NaCl}$ & 0.32 \\
\hline
\end{tabular}

Control diet-95\% w/w Basic diet $+5 \% \mathrm{w} / \mathrm{w}$ wheat; Experimental diet-95\% w/w Basic $\operatorname{diet}+5 \% \mathrm{w} / \mathrm{w}$ fermented apple pomace. 
Table 3. Effect of diet on average daily gain and average daily feed intake.

\begin{tabular}{ccccc}
\hline \multirow{2}{*}{ Week } & \multicolumn{2}{c}{ Average Daily Gain (kg/day) } & \multicolumn{2}{c}{ Average Daily Feed Intake (kg/day) } \\
\cline { 2 - 5 } & Control Diet & Experimental Diet $^{\text {Control Diet }}$ & Experimental Diet \\
\hline 1 & $0.721 \pm 0.132^{\mathrm{a}}$ & $0.637 \pm 0.046^{\mathrm{a}}$ & $2.601 \pm 0.028^{\mathrm{x}}$ & $2.928 \pm 0.024^{\mathrm{xy}}$ \\
2 & $1.136 \pm 0.423^{\mathrm{b}}$ & $1.267 \pm 0.073^{\mathrm{b}}$ & $2.978 \pm 0.032^{\mathrm{xy}}$ & $3.114 \pm 0.042^{\mathrm{y}}$ \\
3 & $1.815 \pm 0.071^{\mathrm{c}}$ & $1.934 \pm 0.075^{\mathrm{c}}$ & $3.011 \pm 0.046^{\mathrm{y}}$ & $3.325 \pm 0.046^{\mathrm{yz}}$ \\
4 & $2.446 \pm 0.113^{\mathrm{d}}$ & $2.601 \pm 0.080^{\mathrm{d}}$ & $3.290 \pm 0.054^{\mathrm{yz}}$ & $3.504 \pm 0.062^{\mathrm{z}}$ \\
\hline
\end{tabular}

All data are the mean \pm SD of three replicates. Mean followed by different letters in the same column differ significantly $(p<0.05)$ between the control and experimental diet.

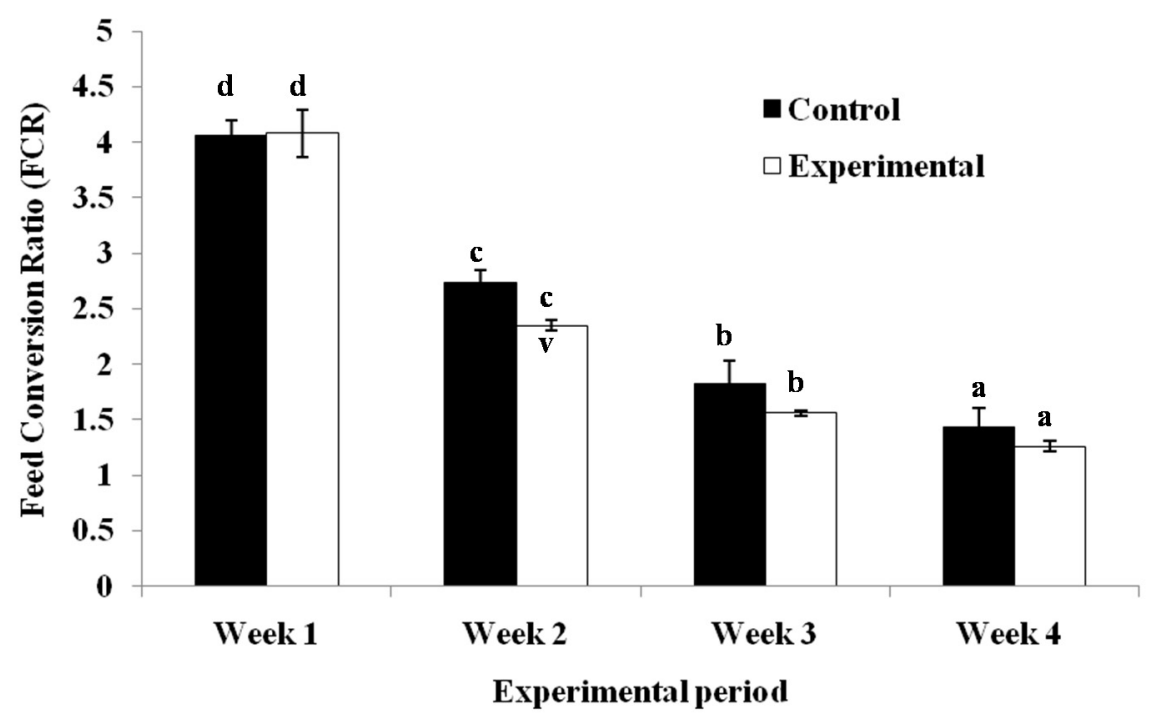

Figure 1. Effect of protein enriched diet on feed conversion ratio. All data are the mean $\pm \mathrm{SD}$ of three replicates. Mean followed by different letters in the same column differ significantly $(p<0.05)$ between the control and experimental diet.

In the case of the experimental diet, the average daily gain was in the range of $0.637 \pm 0.05 \mathrm{~kg} / \mathrm{day}$ to $2.60 \pm 0.08 \mathrm{~kg} /$ day (Table 3 ). There was slight increase of average daily gain in the experimental diet animal group compared to control diet group. This increase in average daily gain may be due to the higher content of protein in experimental diet.

The average daily feed intake during the animal experiment in control group was in the range of $2.60 \pm 0.03$ to $3.29 \pm 0.05 \mathrm{~kg} /$ day and it was in the range of $2.93 \pm 0.02$ to $3.50 \pm 0.06 \mathrm{~kg} / \mathrm{day}$ for the treated group (supplied with 5\% fermented pomace supplement). In general, it was noted that there was no aversion of the experimental diet formulated with fermented apple pomace. This is clear from the similar trend in the average daily feed intake by the animals in both the control diet and experimental diet groups.

The feed conversion ratio during the experiment was in the range of 4.06 to 1.46 in control group and 4.08 to 1.13 in the experimental diet group (Figure 1). Improving feed conversion is a matter of either decreasing the amount of feed fed or increasing the amount of weight gained or both the factors. It was also important that the feed conversion ratio was higher in the first two weeks of the animal experiment and gradually decreased in both control and experiment diet groups. This may be due to the change in growth rate during the first weeks of the growth period. 
The term feed conversion ratio is utilized to indicate the quantity of feed required to lay down a unit of body tissue. The feed conversion ratio is used as indicators of the performance standard of a production system. The Feed Conversion Ratio (FCR) is a reflection of performance in animals. Feed intake and weight gain are the integral components which influence FCR. FCR performance within a group of animals can vary widely. In fact, FCR is not an index based on the variables of growth rate and feed intake but based on the factors affecting them. It is not just a calculated value but an independent biological factor that can be influenced by genetics, feeding practice, environmental control or health status. In general, the faster the growth, the better the conversion efficiency. The FCR is only a measure of the ability of the animal to convert diets into growth at that particular condition. Factors that affect growth rate and feed consumption and utilization will also affect efficiency of conversion.

These results demonstrated the fact that the protein produced by the fungus $P$. chrysosporium during protein enrichment of the apple pomace enabled its use as a feed supplement in diets for pigs, representing a useful value-addition for the apple pomace and other agro-industrial residues. Besides avoiding the dumping of this residue directly into the environment and thereby reducing the levels of environmental pollution, this application also reduces the costs of feed, which represent around $60 \%$ of the production cost [15].

\subsection{Water Consumption and Feed Consumption during the Experiment}

The water and feed consumption during the four weeks of experimental period for both the control and experimental diet group has been recorded daily. The water consumption by the control and experimental diet group animal are given in the Figure 2. The water consumption in the control group and the experimental group increased depending on the experimental period from 5.18 to $5.26 \mathrm{~L} /$ day and from 4.95 to $5.05 \mathrm{~L}$ /day respectively. The consumption of feed was determined as shown in the Figure 3 and the feed consumption index (C.I.) with respect to fresh weight was calculated from fresh weight of feed intake and fresh weight of animal.

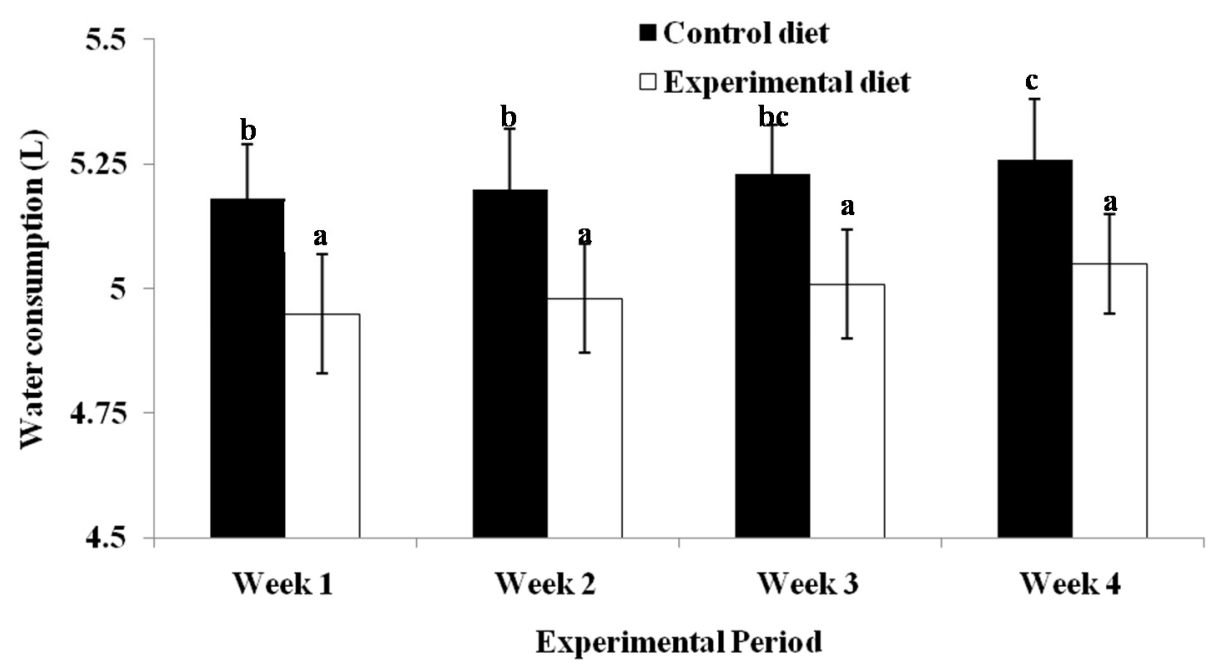

Figure 2. Water consumption during the experimental period. All data are the mean $\pm \mathrm{SD}$ of three replicates. Mean followed by different letters in the same column differ significantly $(p<0.05)$ between the control and experimental diet. 
The water consumption was higher in the control diet group compared to the experimental group (Figure 2). In the experimental group, $5 \% \mathrm{w} / \mathrm{w}$ of the normal diet, mainly wheat was replaced by fermented apple pomace. The fermented apple pomace is easily digestible than the normal grains, which probably in turn leads to lower consumption of water in the experimental group. This shows the favorable effect of the fermented pomace as a supplement in the normal feed.

The consumption of feed was determined as shown in Figure 3 and the feed consumption index (C.I.) is an indicator of relative intake of nutrients. The index as calculated underestimates absolute amount of food consumed due to the water content of the medium. No differences in consumption index were observed among the control and experimental diet group during the first two weeks. Later, there was a slight increase in the consumption index among the control and experimental diet group during the third and fourth week. This increase in consumption index during the third and fourth week may be due to the increase in growth of the animals and the easy availability of nutrients to the animal.

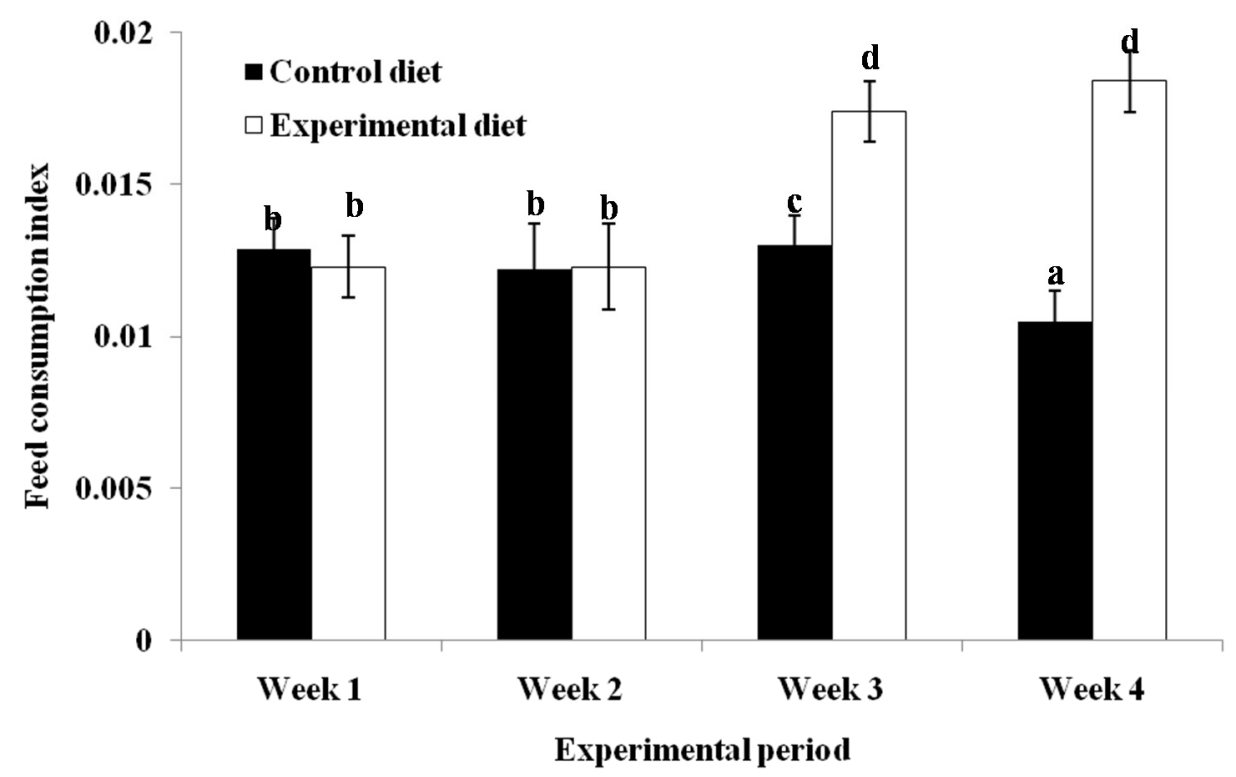

Figure 3. Feed Consumption index during the experiment. All data are the mean \pm SD of three replicates. Mean followed by different letters in the same column differ significantly $(p<0.05)$ between the control and experimental diet.

Matoo et al., (2001) have reported better performance of broilers chickens fed on apple pomace diets supplemented with enzymes [16]. It was reported that apple by-products replaced the maize in normal diet of broiler chicken improved the growth performance and were also reported to reduce the cost of poultry feed [17].

\subsection{Effect of Feed on Efficiency of Conversion of Ingested Feed (ECI)}

The efficiency of conversion (ECI) of ingested feed increased with the experimental period in both the control and the experimental diet group and the ECI of both control and experimental diet group is given in the Table 4. The efficiency of conversion of ingested food increased from $43.5 \pm 2.5$ to $83.3 \pm 4.4$ during the experimental period in the control diet group, whereas in the case of experimental diet, the efficiency of conversion of feed increased from $55.4 \pm 4.5$ to $92.1 \pm 3.6$. 
Table 4. Effect of feed on efficiency of conversion of ingested feed (ECI).

\begin{tabular}{ccc}
\hline Week & Control diet & Experimental diet \\
\hline 1 & $43.46 \pm 2.50^{\mathrm{a}}$ & $55.36 \pm 4.50^{\mathrm{b}}$ \\
2 & $72.98 \pm 4.80^{\mathrm{c}}$ & $85.14 \pm 6.20^{\mathrm{d}}$ \\
3 & $79.14 \pm 6.80^{\mathrm{e}}$ & $88.48 \pm 8.40^{\mathrm{f}}$ \\
4 & $83.14 \pm 4.40^{\mathrm{f}}$ & $92.08 \pm 3.60^{\mathrm{g}}$ \\
\hline
\end{tabular}

All data are the mean \pm SD of three replicates. Mean followed by different letters in the same column differ significantly $(p<0.05)$ between the control and experimental diet.

The term feed conversion efficiency (ECI) is utilized to indicate the quantity of feed required to lay down a unit of body tissue. ECI used as indicators of the performance standard of a production system. The higher the quality of the feed, in general, the better the animal will convert it to body tissue. The more palatable the feed, the higher the intake, which in turn gives better conversion rate. The faster the growth, the conversion efficiency will be better. Factors that affect growth rate and feed consumption and utilization will also affect efficiency of conversion.

It is noteworthy that the improving digestibility of nutrients leads to improvement in nutritive value of diet which in turn improves the growth performance of the animal. It has been reported that exogenous enzymes (cellulase, xylanase, alpha-amylase and polygalacturonase) treatment were good methods for enhancing the growth performance and digestibility of ration containing pearl millet without any hazard on buffalo health [18]. Rao et al. (2004) found that the performance of broiler chicks fed diets containing pearl millet (Pennisetum glaucum) with and without enzymes comprising amylase, hemicellulase, cellulase, proteinase and beta-glucanase improved the immunological traits and reduced total cholesterol in the tissue of broilers [19]. The effects of beta-glucosidase on feed usage, growth performance, and activities of digestive enzyme and a set of physiological parameters in broilers have been studied and showed positive impact on the growth performance of the broilers [20]. A study conducted by Omogbenigun et al. (2004) reported that an improvement in average daily gain had been observed in piglet fed diets based on corn and wheat supplemented with an enzyme cocktail containing cellulase, galactanase, mannanase, and pectinase [21]. Significant benefits to xylanase supplementation were demonstrated in growing pigs fed corn-based diets in terms of the growth rate [22]. Besides, Kim et al. (2001) observed that average daily growth was increased by $3 \%$ and $7 \%$, respectively, with $0.1 \%$ enzyme complex supplementation to corn and soybean meal based diets for weaned piglets [23].

\subsection{Nutrient Assimilation Efficiency in Control and Experimental Diets}

The nutrient assimilation efficiency for different nutrients, such as protein, lipid and minerals has been determined and given in Table 5. The nutrient assimilation efficiency for protein increased from $91.15 \% \pm 0.2 \%$ (control) to $93.46 \% \pm 0.8 \%$ (experimental). This increase in protein assimilation in the experimental group may be due to the higher protein content, which was easily assimilated in the case of fermented pomace. The concentration of protein in fermented substrate (apple pomace) increased significantly $(p<0.05)$ during fermentation. There was not much difference in mineral assimilation efficiency between the control and experimental diet group. 
Table 5. Nutrient assimilation efficiency in control and experimental diets fed to pigs.

\begin{tabular}{ccc}
\hline \multirow{2}{*}{ Component } & \multicolumn{2}{c}{ \% of Nutrient Assimilation } \\
\cline { 2 - 3 } & Control Diet & Experimental Diet \\
\hline Crude Protein & $91.2 \pm 2$ & $93.5 \pm 8$ \\
Lipid & $93.1 \pm 1$ & $91.3 \pm 2$ \\
Phosphorus & $86.4 \pm 1$ & $84.6 \pm 8$ \\
Potassium & $77.5 \pm 2$ & $78.9 \pm 4$ \\
Calcium & $88.7 \pm 4$ & $84.9 \pm 2$ \\
Magnesium & $79.1 \pm 8$ & $78.7 \pm 6$ \\
Boron & $79.2 \pm 6$ & $81.2 \pm 2$ \\
Aluminum & $85.5 \pm 5$ & $84.0 \pm 4$ \\
Copper & $78.4 \pm 8$ & $72.8 \pm 6$ \\
Iron & $80.9 \pm 3$ & $74.0 \pm 8$ \\
Manganese & $76.6 \pm 4$ & $74.3 \pm 6$ \\
Zinc & $75.7 \pm 1$ & $75.8 \pm 4$ \\
Sodium & $79.4 \pm 4$ & $81.2 \pm 6$ \\
\hline
\end{tabular}

All data are the mean $\pm \mathrm{SD}$ of three replicates.

Diet choice should reflect selective feeding to maximize the rate of net energy gain [24]. Energy value of the diet, assimilation efficiency and nutrient content (in particular $\mathrm{N}$ or protein) are the factors generally considered when assessing food value relative to diet choice. Assimilation efficiencies were calculated by comparing organic and ash contents of the food with the corresponding fecal material, using ash as a non-absorbed reference marker. This increase in protein assimilation in the experimental diet group may be due to the higher protein content, which was easily assimilated in the case of fermented pomace. There was not much difference in mineral assimilation efficiency between the control and experimental diet group.

Earlier, it has been reported that the fermentation improved the nutritional levels of the apple pomace [25]. The concentration of protein fermented substrate increased significantly $(p<0.05)$ during fermentation. It was reported that total amino acids as well as the essential amino acids were increased remarkably reaching $46.8 \%$ and $71.7 \%$, respectively [25].

\subsection{Effect of Feed on Air Quality}

The effect of feed on air quality has been determined in terms of odor and greenhouse gas emission. The odor emissions were measured for last two weeks and ranged from 4.8 to $7.6 \mathrm{ouE} / \mathrm{s} / \mathrm{head}$ (Table 6) in control and experimental diet group. The results showed that the treatment had no significant impact on gas emissions (Table 7). The average $\mathrm{CH}_{4}$ and $\mathrm{CO}_{2}$ emissions were $0.0138 \mathrm{~g} / \mathrm{day} / \mathrm{kg}$ and $52 \mathrm{~g} / \mathrm{day} / \mathrm{kg}$ for the control diet and $0.0299 \mathrm{~g} / \mathrm{day} / \mathrm{kg}$ and $69 \mathrm{~g} /$ day $/ \mathrm{kg}$ for the treatment diet. The emission of $\mathrm{NH}_{3} \mathrm{during}$ the experiment was 0.11 to $0.13 \mathrm{~g} / \mathrm{day} / \mathrm{kg}$ in the control and 0.11 to $0.14 \mathrm{~g} / \mathrm{day} / \mathrm{kg}$ in the experimental diet group. 
Table 6. Effect of control and experimental diet on environmental parameter values.

\begin{tabular}{|c|c|c|c|c|c|c|c|c|c|c|c|c|}
\hline & \multicolumn{2}{|c|}{$\begin{array}{l}\text { Temp } \\
\left({ }^{\circ} \mathrm{C}\right)\end{array}$} & \multicolumn{2}{|c|}{$\begin{array}{c}\text { Ventilation } \\
\text { L/s/pig }\end{array}$} & \multicolumn{2}{|c|}{$\begin{array}{c}\text { Water } \\
\text { L/day/pig }\end{array}$} & \multicolumn{2}{|c|}{$\begin{array}{c}\text { Odor Emission } \\
\text { ouE/s/pig }\end{array}$} & \multicolumn{2}{|c|}{$\begin{array}{c}\text { Odor Concentration } \\
\qquad \mathrm{ouE} / \mathbf{m}^{3}\end{array}$} & \multicolumn{2}{|c|}{$\begin{array}{c}\text { Hedonic } \\
\text { Tone }\end{array}$} \\
\hline & Cont & Expt & Cont & Expt & Cont & Expt & Cont & Expt & Cont & Expt & Cont & Expt \\
\hline Week 1 & 19.5 & 19.5 & 19.6 & 18.1 & 4.1 & 4.6 & & & & & & \\
\hline Week 2 & 18.9 & 18.9 & 19.7 & 18.4 & 4.4 & 4.5 & & & & & & \\
\hline Week 3 & 18.5 & 18.5 & 20.4 & 19.2 & 5.1 & 4.8 & 6.5 & 7.6 & 341 & 410 & 0.9 & -0.7 \\
\hline Week 4 & 18.1 & 18.0 & 21.2 & 19.7 & 5.4 & 5.4 & 6.4 & 4.8 & 310 & 261 & 1.0 & -1.1 \\
\hline
\end{tabular}

Table 7. GHG emission values for each diet treatment and growth period.

\begin{tabular}{|c|c|c|c|c|c|c|c|c|c|}
\hline \multirow{2}{*}{ Weeks } & \multirow{2}{*}{ Weight (kg) } & \multicolumn{2}{|c|}{$\mathrm{CH}_{4}$} & \multicolumn{2}{|c|}{$\mathrm{CO}_{2}$} & \multicolumn{2}{|c|}{$\mathbf{N}_{2} \mathbf{O}$} & \multicolumn{2}{|c|}{$\mathrm{NH}_{3}$} \\
\hline & & Cont & Expt & Cont & Expt & Control & Expt & Control & Expt \\
\hline 1.0 & 52.5 & 0.0126 & 0.0324 & 70 & 95 & 2.02 & 2.20 & 0.13 & 0.14 \\
\hline 2.0 & 62.2 & 0.0160 & 0.0373 & 66 & 85 & 2.13 & 2.28 & 0.13 & 0.14 \\
\hline 3.0 & 69.1 & 0.0188 & 0.0346 & 59 & 80 & 2.24 & 2.12 & 0.12 & 0.13 \\
\hline 4.0 & 77.0 & 0.0138 & 0.0299 & 52 & 69 & 2.07 & 2.33 & 0.11 & 0.11 \\
\hline
\end{tabular}

$\mathrm{CH}_{4}, \mathrm{~g} /$ day $/ \mathrm{kg} ; \mathrm{CO}_{2}, \mathrm{~g} /$ day $/ \mathrm{kg} ; \mathrm{N}_{2} \mathrm{O}, \mathrm{mg} /$ day $/ \mathrm{kg} ; \mathrm{NH}_{3}, \mathrm{~g} /$ day $/ \mathrm{kg}$.

\subsubsection{Odor Emission}

The treatment had no significant impact on odor emissions. The odor emissions were determined for 3-4 weeks of the experimental period and ranged from 4.8 to $7.6 \mathrm{ouE} / \mathrm{s} / \mathrm{head}$ (Table 6 ) and were found to be in the same range as the literature values [26]. Due to the odor produced by apples as such, the hedonic tone was lower using the experimental diet than the control diet. However, due to the insufficient data, no statistical analysis has been performed.

\subsubsection{Greenhouse Gas (GHG) Emission}

The results showed that the treatment had no significant impact on gas emissions (Table 7). The ammonia emissions measured were 7.9 and $8.4 \mathrm{~g}$ /day/head and it was very close to values reported by Hamelin et al. (2009) [26]. On average, the emissions from growing finishing pig under Quebec condition are $\mathrm{NH}_{3}=5.48 \mathrm{~g} /$ day/head; $\mathrm{CH}_{4}=2.26, \mathrm{CO}_{2}=1.940 \mathrm{~kg} /$ day $/$ head and no $\mathrm{N}_{2} \mathrm{O}$ emissions have been measured [26]. There may some other reason which played a role in GHG emission other than the nutrient management during the feeding trial, such as manure and farm house management. Further experiments are in progress which focuses on feed management to reduce crude protein intake keeping higher growth performance as well as lowering GHG emissions.

Many environmental organizations have established threshold values for $\mathrm{NH}_{3}$ in ambient air. On average, the $\mathrm{NH}_{3}$ chronic exposure limit varies from 100 to $300 \mathrm{ppb}$, whereas the acute exposure limit ranges from 1700 to $4500 \mathrm{ppb}$. The emission of $\mathrm{NH}_{3}$ during the experiment was 0.11 to $0.13 \mathrm{~g} / \mathrm{day} / \mathrm{kg}$ in the control and 0.11 to $0.14 \mathrm{~g} / \mathrm{day} / \mathrm{kg}$ in the experimental diet group. This concentration of $\mathrm{NH}_{3}$ does not reflect a health risk when compared to chronic and acute exposure limits.

Nutritional management can substantially reduce nitrogen excretion and ammonia emission by pigs. It is generally agreed that feeding low crude protein $(\mathrm{CP})$ diets supplemented with synthetic amino acids lowers urea excretion by pigs, resulting in lower ammonia emission, and the nitrogen excretion is shifted 
from urea in the urine to bacterial protein in the feces when fibrous feedstuffs are included in the diet. It was found that nitrogen excretion in the urine of pigs fed a standard CP diet supplemented with dried apple pomace at the rate of $23.1 \%$ was $36 \%$ lower than with the standard CP diet. It was found that the protein assimilation in the experimental diet was higher (93.5\%) than the control diet $(91.2 \%)$ as shown in Table 5. The higher protein assimilation may indirectly reduce the nitrogen excretion and ammonia emission. A detailed study should be conducted to determine protein assimilation and its role in GHG emission in the future. Earlier, it was reported that when the productivity of animal improved, $\mathrm{CH}_{4}$ emission per unit of product reduced as feed energy associated with maintenance of the animal is reduced [27]. It was reported that $50 \%$ of total nitrogen excreted by pigs could be reduced by modifying the composition of the diet without altering the animal performance by balancing amino acid composition of diets, and phase feeding [28].

\section{Experimental Section}

\subsection{Materials}

Apple pomace samples from the apple processing industry (Lassonde Inc., Rougemont, Montreal, QC, Canada) was collected and used as the solid substrate for the solid-state fermentation. All chemicals required for the experiments have been purchased from Fisher Scientific (Fisher Scientific Company, Ottawa, ON, Canada), VWR chemicals (VWR International, Québec, QC, Canada) and Sigma Chemicals (Sigma-Aldrich Canada Ltd., Ottawa, ON, Canada) and were of analytical grade.

\subsection{Solid State Fermentation}

Medium for fermentation: Apple pomace was used as natural substrate for solid-state fermentation [12]. The apple pomace solids were stored at $-20{ }^{\circ} \mathrm{C}$ for its conservation prior to use. For the fermentation, apple pomace was treated with inducers, such as copper sulfate $(2 \mathrm{mM})$, veratryl alcohol $(2 \mathrm{mM})$ and Tween-80 $(0.1 \% \mathrm{v} / \mathrm{v})$ and the $\mathrm{pH}$ was adjusted to 4.5 and it was sterilized in an autoclave for $30 \mathrm{~min}$ at $121 \pm 1{ }^{\circ} \mathrm{C}$. The moisture content in the apple pomace was $72 \% \mathrm{w} / \mathrm{v}$.

Microorganisms: P. chrysosporium (ATCC 24275) was selected as a suitable microorganism for bio-processing of solid state fermentation for its potential for higher enzyme production. $P$. chrysosporium was maintained on potato-dextrose-agar (PDA) medium at $4 \pm 1{ }^{\circ} \mathrm{C}$. The culture of $P$. chrysosporium was grown on PDA petri plate and incubated at $37 \pm 1{ }^{\circ} \mathrm{C}(96 \mathrm{~h})$. The spores were harvested from the sporulation medium plates and inoculated into sterile distilled water contained in test tubes and stored in the freezer until use. The fermented broth was initially filtered through glass wool to remove mycelial contamination and recover only the spores. The concentration of spore suspension used in the experiments was $2.5 \times 10^{6} \mathrm{spores} / \mathrm{g}$ of solid.

Solid-state fermentation in tray: The fermentation was carried out in $5 \mathrm{~L}$ capacity plastic tray bioreactors $(0.03 \mathrm{~m} \times 0.018 \mathrm{~m} \times 0.012 \mathrm{~m})$. The sterilized medium containing $0.5 \mathrm{~kg}$ apple pomace was transferred into the sterilized tray in an aseptic condition. The inoculation was carried out using spore suspension. The fermentation was carried out in an environmental chamber (Percival Scientific, Perry, IA, USA) at $37 \pm 1{ }^{\circ} \mathrm{C}$ and relative humidity ranged from $72 \%-74 \%$. The fermentation was carried out for 10 days with occasional mixing for proper aeration and the samples were periodically drawn. The 
fermented apple pomace was dried at $60{ }^{\circ} \mathrm{C}$ for $48 \mathrm{~h}$ and the dried fermented apple pomace was milled and sieved using $3 \mathrm{~mm}$ size sieve. The powdered fermented apple pomace was ultimately used for the preparation of the experimental diet.

\subsection{Diet}

The main dietary ingredients in the basic diets were maize, soybean, mineral, and vitamin mix and phytase enzymes as shown in Table 2. Premixes were added to meet or exceed mineral and vitamin requirements [29]. For the control diet used for the experiment, $5 \% \mathrm{w} / \mathrm{w}$ of the basic diet was replaced by $5 \% \mathrm{w} / \mathrm{w}$ of wheat and for the experimental diet, $5 \% \mathrm{w} / \mathrm{w}$ of the basic diet was replaced by powdered fermented apple pomace. The animals showed aversion to the larger chunks of fermented apple pomace during the trial diet experiments with fermented apple pomace. Hence, for the final studies, powdered apple pomace was used.

\subsection{Animal Experimental Design}

The animal protocol for the study was followed as per the principles established by the Canadian Council on Animal Care (CCAC, 2009) [30]. The experiments were conducted at the experimental farm at research center of the Institut de recherche et de développement en agroenvironnement (IRDA, Deschambault, QC, Canada). In total, 12 pigs were weaned at $17 \pm 1$ day of age and healthy animals were selected for the experiment.

The experimental laboratory farm consisted of 12 identical and independent chambers laid out side-by-side. Six of them have been used for the project. Each room is equipped with a fully concrete slatted floor and has its own manure handling system. Two growing-finishing pigs were housed per chamber during seven weeks ( 2 weeks of accommodation and 4 weeks of testing).

The ventilation system consisted of an inlet and exhaust fan mounted in the ceiling of each chamber. The exhaust fan was able to vary the capacity from 14 to $75 \mathrm{~L} / \mathrm{s}$. The exhaust air was directed through a 204-mm iris orifice damper (Model 200; Continental fan manufacturer Inc., Buffalo, NY, USA). Its accuracy was rated at $\pm 5 \%$. A differential pressure transducer measured the pressure across the orifice plate. The temperature $\left(17-18{ }^{\circ} \mathrm{C}\right)$ and the humidity $(39 \%-52 \%)$ was maintained for a particular range during the entire experiment. The chambers were equipped with self-feeder and tabulated drinker. Pigs had free access to feed and water during the entire 4-week study. Three chambers were fed with control diet and three chambers were fed with experimental diet. All animal-related data (feed and water consumption, weight gain, volume of manure) as well as manure samples were taken weekly. Weekly, individual pigs were weighed to monitor weight gain and the amount of feed consumed was determined. Freshly voided feces were collected from each chamber. Feces were pooled by chambers and frozen at $-20{ }^{\circ} \mathrm{C}$. Upon completion of the growth trial, feces were thawed, homogenized, sub-sampled and used for the chemical analyses.

Feed consumed, water intake, weight gained, feed conversion ratio and mortality was regularly recorded. The efficiency of the feeds given to the pigs were analyzed on the basis of consumption index, growth rate, efficiency of conversion of ingested feed and digestibility of feed, as described by Waldbauer (1968) [31]. Assimilation efficiencies were calculated following a commonly used procedure 
in which the nutrient content of the food is compared with that of the feces using ash as an assumed non-absorbed marker [32]. The formulas used for the analysis has been given in Equations (1) to (5).

Consumption index $=$ Weight of feed eaten/Mean weight of animal $\times$ Duration of experiment during feeding trial

Growth rate $(\mathrm{GR})=$ Weight gained by the animals/Mean weight of animal $\times$ Duration of feeding trial during feeding trial

Efficiency of conversion of ingested food to body substance (E.C.I.) $=100 \times \mathrm{wt}$ gained/wt food intake

Efficiency of conversion of digested food to body substance (E.C.D.) $=100 \times \mathrm{wt}$ gained/(wt food intake - wt of feces)

Nutrient assimilation efficiency $(\%)=1-(\%$ of Ash in food $/ \%$ of Ash in Feces $) \times$ $(\%$ of nutrient in feces $/ \%$ of nutrient in food $) \times 100$

\subsection{Chemical Analyses of Diet and Feces}

Control and experimental diets and feces were analyzed for crude protein (CP), crude fat, ADF (Acid detergent fiber), NDF (Neutral Detergent Fiber) and ash (Association of Official Analytical Chemists, AOAC, 2006) [33]. Metal concentrations in the diets and feces were analyzed by ICP-AES (Varian Vista AX, Palo Alto, CA, USA) after a complete acid digestion of sample using $\mathrm{HNO}_{3}, \mathrm{HClO}_{4}, \mathrm{HF}$ and $\mathrm{HCl}$. The quality control of elemental analysis by ICP-AES was performed with two certified liquid samples (multi-element standard, catalog number 900-Q30-100 (lot SC-8305871) and 990-Q30-101 (lot SC7256497), SCP Science, Lasalle, QC, Canada). The standards used for ICP-AES allowed the quantitative measurement of 22 elements in the sample sediments (Al, As, Ba, $\mathrm{Ca}, \mathrm{Cd}, \mathrm{Co}, \mathrm{Cr}, \mathrm{Cu}, \mathrm{Fe}$, $\mathrm{K}, \mathrm{Mg}, \mathrm{Mn}, \mathrm{Mo}, \mathrm{Na}, \mathrm{Ni}, \mathrm{P}, \mathrm{Pb}, \mathrm{S}, \mathrm{Si}, \mathrm{Sn}, \mathrm{Tn}$, and Zn).

\subsection{Air Quality Measurements}

The chambers were provided with uniform heating and ventilation rates, and with instrumentation to continuously measure temperature, relative humidity using a type $\mathrm{T}$ thermocouple and electronic humidity sensor (Model CHG-UGS, TDK Corporation of America, Mount Prospect, IL, USA). Each sensor was scanned every $10 \mathrm{sec}$ and the average was recorded every $15 \mathrm{~min}$. The concentration of methane $\left(\mathrm{CH}_{4}\right)$, carbon dioxide $\left(\mathrm{CO}_{2}\right)$ and nitrous oxide $\left(\mathrm{N}_{2} \mathrm{O}\right)$ was measured with a gas chromatograph (Varian 3600, Palo Alto, CA, USA) equipped with a flame ionization detector (FID) for detection and quantification of $\mathrm{CH}_{4}$ and an electron capture detector (ECD) for detection and quantification of $\mathrm{CO}_{2}$ and $\mathrm{N}_{2} \mathrm{O}$. Ammonia was measured with a non-dispersive infra-red (NDIR) analyzer (Ultramat 6E, Siemens, Berlin, Germany) and the semi-quantitative evaluation of hydrogen sulphide $\left(\mathrm{H}_{2} \mathrm{~S}\right)$ was carried out using a UV fluorescence analyzer (M101E, Teledyne API, San Diego, CA, USA). Every two days, the analyzers would monitor ambient air and certified calibration gas.

Odor samples were collected one time during the two last weeks. Odor concentration and hedonic tone were evaluated by dynamic olfactometry. Air samples at the air room intake and exhaust were collected in 60-L flushed Nalophane bags for odor evaluation. The olfactometry (Nasal Ranger ${ }^{\mathrm{TM}}$, 
St. Croix Sensory Inc., Stillwater, MN, USA) tests were carried out in a $24 \mathrm{~h}$ period from the sampling time.

\subsection{Statistical Analyses}

All the experiments were conducted in replicate and data presented are an average of replicates along with the standard deviation. The database was subjected to an analysis of variance (ANOVA) and multiple range tests among data were carried out using the Statistical Analysis System Software (STATGRAPHICS Centurion, XV trial version 15.1.02 year 2006, StatPoint, Inc., Warrenton, VA, USA) and the results which have $p<0.05$ were considered as significant. The method used to discriminate among the means is Fisher's least significant difference (LSD) procedure. Using this method, there is a $5.0 \%$ risk of calling each pair of means significantly different when the actual difference equals 0 .

\section{Conclusions}

Apple pomace was found to be a good substrate for the production of a protein feed rich in higher content of soluble proteins and the rapid colonization of the substrate by the fungus P.chrysosporium suggesting a potential use of this agro-industrial residue. There was a $36 \%$ increase in protein content in the experimental diet by using 5\% fermented apple pomace. The fermented apple pomace incorporated into the diet of the pigs was a nutritive product and improved the performance of the animals. These results demonstrate that the protein produced by the fungus $P$. chrysosporium in the protein enrichment by solid-state cultivation of the apple pomace enhance its use as a dietary supplement in swine diet. From the improved performance of animals, it can be concluded that the microbial protein supplied the energy demand of the animals.

Modification of diets in terms of its nutrient content was found to have a dual impact on both enteric and manure GHG emissions and was cost effective in terms of feed and livestock management. Furthermore, there is a great deal of uncertainty associated with emissions from the manure management systems, including loss of $\mathrm{N}$ associated with different handling systems, storage and application and therefore reduction strategies cannot be effectively assessed.

\section{Acknowledgments}

The authors are sincerely thankful to the Natural Sciences and Engineering Research Council of Canada (Discovery Grant 355254, Canada Research Chair), FQRNT (ENC 125216), MAPAQ (No. 809051) and Projet Initiative Inde 2010 for financial support. The views or opinions expressed in this article are those of the authors.

\section{Author Contributions}

Experiments were designed, performed and samples were analyzed by C.M. Ajila. Data analysis and manuscript preparation were jointly completed by C.M. Ajila and S.J. Sarma. All other authors have equally participated in supervising the work and finalization the manuscript. 


\section{Conflicts of Interest}

The authors declare no conflict of interest.

\section{List of Abbreviations}

Acid detergent fiber (ADF)

Association of Official Analytical Chemists (AOAC)

Canadian Council on Animal Care (CCAC)

Consumption index (C.I.)

Control (Cont)

Efficiency of conversion (ECI)

European Odor Units (ouE)

Experimental (Expt)

Feed Conversion Ratio (FCR)

Flame ionization detector (FID)

Greenhouse gas (GHG)

Growth rate (GR)

Least significant difference (LSD)

Neutral Detergent Fiber (NDF)

Non-dispersive infra-red (NDIR)

Solid State Bio-processing (SSF)

Temperature (Temp)

\section{References}

1. Shah, A.R.; Madamwar, D. Xylanase production under solid-state fermentation and its characterization by an isolated strain of Aspergillus foetidus in India. World J. Microbiol. Biotechnol. 2005, 21, 233-243.

2. Rumsey, T. Ruminal fermentation products and plasma ammonia of fistulated steers fed apple pomace-urea diets. J. Anim. Sci. 1978 47, 967-976.

3. Correia, R.; Magalhaes, M.; Macedo, G. Protein enrichment of pineapple waste with Saccharomyces cerevisiae by solid state bioprocessing. J. Sci. Indus. Res. 2007, 66, 259-262.

4. Joshi, V.; Sandhu, D. Preparation and evaluation of an animal feed byproduct produced by solid-state fermentation of apple pomace. Bioresour. Technol. 1996, 56, 251-255.

5. Bhalla, T.; Joshi, M. Protein enrichment of apple pomace by co-culture of cellulolytic moulds and yeasts. W. J. Microbiol. Biotechnol. 1994, 10, 116-117.

6. Devrajan, A.; Joshi, V.K.; Gupta, K.; Sheikher, C.; Lal, B.B. Evaluation of apple pomace based reconstituted feed in rats after solid state fermentation and ethanol recovery. Braz. Archi. Biol. Technol. 2004, 47, 93-106.

7. Joshi, V.; Gupta, K.; Devrajan, A.; Lal, B.; Arya, S. Production and evaluation of fermented apple pomace in the feed of broilers. J. Food Sci.Technol. 2000, 37, 609-612. 
8. Steinfeld, H.; Gerber, P.; Wassenaar, T.; Castel, V.; Rosales, M.; Haan, C.D. Livestock's Long Shadow: Environmental Issues and Options; Food and Agriculture Organization of the United Nations (FAO): Rome, Italy, 2006.

9. Determining the Environmental Burdens and Resource Use in the Production of Agricultural and Horticultural Commodities. IS0205. Available online: http://randd.defra.gov.uk/Default.aspx? Menu=Menu\&Module=More\&Location=None\&Completed $=0 \&$ ProjectID=11442 $($ accessed on 27 January 2015).

10. Cederberg, C.; Sonesson, U.; Henriksson, M.; Sund, V.; Davis, J. Greenhouse Gas Emissions from Swedish Production of Meat, Milk and Eggs 1990 and 2005; SIK-Institutet för livsmedel och bioteknik: Gothenburg, Sweden, 2009.

11. Greenhouse Gas Reduction via Nutrition. Available online: http://www.allaboutfeed.net/ Home/General/2010/11/Greenhouse-gas-reduction-via-nutrition-AAF011538W/ (accessed on 27 January 2015).

12. Ajila, C.; Gassara, F.; Brar, S.K.; Verma, M.; Tyagi, R.; Valéro, J. Polyphenolic antioxidant mobilization in apple pomace by different methods of solid-state fermentation and evaluation of its antioxidant activity. Food Bioproc. Technol. 2012, 5, 2697-2707.

13. Zheng, Z.; Shetty, K. Cranberry processing waste for solid state fungal inoculant production. Process Biochem. 1998, 33, 323-329.

14. Bisaria, R.; Madan, M.; Vasudevan, P. Utilisation of agro-residues as animal feed through bioconversion. Bioresour. Technol. 1997, 59, 5-8.

15. Small Acreage. Available online: http://www.colostate.edu/Dept/CoopExt/Adams/sa/livestock.htm (accessed on 27 January 2015).

16. Matoo, F.; Beat, G.; Banday, M.; Ganaie, T. Performance of broilers fed on apple pomace diets supplemented with enzyme(s). Ind. J. Anim. Nutr. 2001, 18, 349-352.

17. Zafar, F.; Idrees, M.; Ahmed, Z. Use of apple by-products in poultry rations of broiler chicks in karachi. Pak. J. Physiol. 2005, 1, 1-2.

18. El-Kady, R.; Awadalla, I.; Mohamed, M.; Fadel, M.; El-Rahman, H.A. Effect of exogenous enzymes on the growth performance and digestibility of growing buffalo calves. Int. J. Agric. Biol. (Pakistan) 2006, 8, 355-359.

19. Effect of Supplemental Enzymes in Diets Containing Yellow Maize or Pearl Millet as a Tropical Source of Energy in Broiler Chicken. Available online: http://agris.fao.org/agris-search/search.do? recordID $=$ IN2006001195 (accessed on 27 January 2015).

20. Qian, L.; Sun, J. Effect of $\beta$-glucosidase as a feed supplementary on the growth performance, digestive enzymes and physiology of broilers. Asian-Austr. J. Anim. Sci. 2009, 22, 260-266.

21. Omogbenigun, F.; Nyachoti, C.; Slominski, B. Dietary supplementation with multienzyme preparations improves nutrient utilization and growth performance in weaned pigs. J. Anim. Sci. 2004, 82, 1053-1061.

22. Fang, Z.; Peng, J.; Liu, Z.; Liu, Y. Responses of non-starch polysaccharide-degrading enzymes on digestibility and performance of growing pigs fed a diet based on corn, soya bean meal and Chinese double-low rapeseed meal. J. Anim. Physiol. Anim. Nutr. 2007, 91, 361-368.

23. Kim, S.; Mavromichalis, I.; Easter, R. Supplementation of alpha-1galactosidase and beta-1, 4-mannanase to improve soybean meal utilization by nursery pig. J. Anim. Sci 2001, 79, 106. 
24. Horn, M. Optimal diets in complex environments: Feeding strategies of two herbivorous fishes from a temperate rocky intertidal zone. Oecologia 1983, 58, 345-350.

25. Zhong-Tao, S.; Lin-Mao, T.; Cheng, L.; Jin-Hua, D. Bioconversion of apple pomace into a multienzyme bio-feed by two mixed strains of Aspergillus niger in solid state fermentation. Electron. J. Biotechnol. 2009, 12, 2-3.

26. Hamelin, L.; Godbout, S.; Lemay, S.P. Baseline scenario for gas, odor, dust and particulate matter emissions from swine buildings in Québec-part I: Emissions inventory. In Proceedings of the CSBE/SCGAB 2009 Annual Conference Rodd's Brudenell River Resort, Prince Edward Island, Charlottetown, Canada, 12-15 July 2009.

27. Wittenberg, K.; Boadi, D. Reducing Greenhouse Gas Emissions from Livestock Agriculture in Manitoba. Manitoba Climate Change Task Force, Public Consultation Sessions 2001. Available online: https://www.iisd.org/taskforce/pdf/dept_animal_sci.pdf (accessed on 15 April 2015).

28. Pomar, C. Potential for Reducing Ghg Emissions from Domestic Monogastric Animals; Agriculture and Agri-Food Table Climate Change Workshop: Montreal, QC, Canada, 1998.

29. Nutrient Requirements of Swine. Available online: http://www.nap.edu/catalog/6016/nutrientrequirements-of-swine-10th-revised-edition (accessed on 28 January 2015).

30. CCAC Guidelines on: The Care and Use of Farm Animals in Research, Teaching and Testing. Available online: http://www.ccac.ca/Documents/Standards/Guidelines/Farm_Animals.pdf (accessed on 28 January 2015).

31. The Consumption and Utilization of Food by Insects. Available online: http://garfield.library.upenn. edu/classics1982/A1982MZ92300001.pdf (accessed on 28 January 2015).

32. Fris, M.B.; Horn, M.H. Effects of diets of different protein content on food consumption, gut retention, protein conversion, and growth of Cebidichthys violaceus (girard), an herbivorous fish of temperate zone marine waters. J. Exp. Mar. Biol. Ecol. 1993, 166, 185-202.

33. Association of Official Analytical Chemists, AOAC, 2006. Available online: http://www. eoma.aoac.org/ (accessed on 28 January 2015).

(C) 2015 by the authors; licensee MDPI, Basel, Switzerland. This article is an open access article distributed under the terms and conditions of the Creative Commons Attribution license (http://creativecommons.org/licenses/by/4.0/). 